\title{
Structure Based Evolution of a Novel Series of Positive Modulators of the AMPA Receptor.
}

\author{
Craig Jamieson $^{a^{*}}$, John K.F. Maclean ${ }^{a^{*}}$, Christopher I. Brown ${ }^{a}$, Robert A. Campbell ${ }^{a}$, \\ Kevin J. Gillen ${ }^{a}$, Jonathan Gillespie ${ }^{a}$, Bert Kazemier ${ }^{b}$, Michael Kiczun ${ }^{a}$, Yvonne \\ Lamont $^{a}$, Amanda J. Lyons ${ }^{a}$, Elizabeth M. Moir ${ }^{a}$, John A. Morrow ${ }^{a}$, John Pantling ${ }^{a}$, \\ Zoran Rankovic ${ }^{a}$ and Lynn Smith $^{a}$.
}

a)Merck Research Laboratories, MSD, Newhouse, Motherwell, Lanarkshire, ML1 5SH, UK.

b) Merck Research Laboratories, MSD, PO Box 20, Oss, 5340 BH, Netherlands.

This is where the receipt/accepted dates will go; Received Month XX, 2000; Accepted Month XX, 2000 [BMCL RECEIPT]

\begin{abstract}
Starting from compound 1, we utilized biostructural data to successfully evolve an existing series into a new chemotyope with a promising overall profile, exemplified by $\mathbf{X}$.
\end{abstract}

The $\quad \alpha$-amino-3-hydroxy-5-methyl-4-isoxazolepropionic acid (AMPA) receptors belong to the family of ionotropic glutamate ion channels. These receptor complexes are widely expressed in the central nervous system and are considered to mediate the majority of fast excitatory amino acid neurotransmission.[1] The role of AMPA receptors appears to be crucial to facilitating synaptic plasticity and long-term potentiation (LTP), the use dependent enhancement in synaptic efficacy which is believed to underlie various forms of learning and memory. AMPA receptor modulators have been shown to enhance LTP and are, therefore, under serious consideration as therapeutic agents for a range of neurological disorders including schizophrenia, Alzheimer's Disease, Parkinson's disease and ADHD.[2,3]

Our earlier work described the identification of $\mathbf{1}$ through optimization of an HTS derived hit.[4,5] Key properties associated with compound $\mathbf{1}$ and its X-ray cocrystal structure in complex with the S1S2 Ligand Binding Domain (LBD) GluA2 construct is depicted in Figure 1. [6]

\footnotetext{
* Corresponding authors. Phone +44 1698 736496; Fax +44 1698736187 Email: john.maclean@merck.com. Present address (CJ): Dept of Pure \& Applied Chemistry, University of Strathclyde, 295 Cathedral St, Glasgow, G1 1XL. Phone: +44 141548 4830; Fax +44 141548 5743; email: craig.jamieson@strath.ac.uk;
}

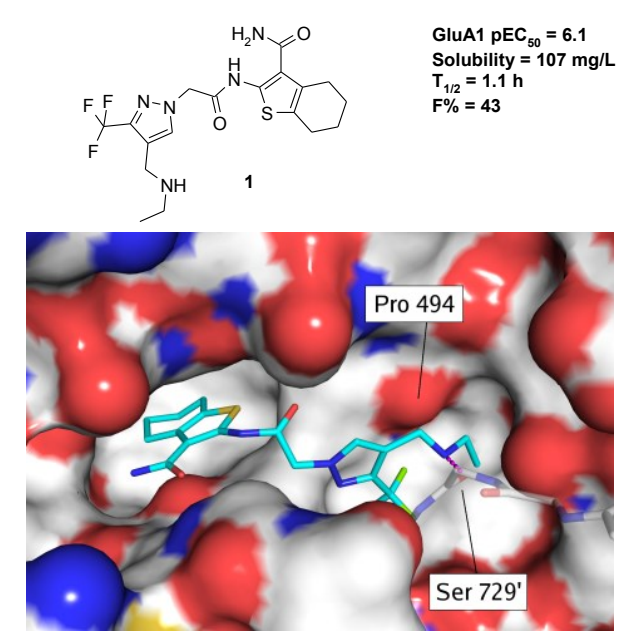

Figure 1. Lead compound 1, summary property data \& structure in complex with the GluA2 S1S2 LBD. As the binding site spans an intramolecular two-axis, two orientations of $\mathbf{1}$ are observed in the crystal structure, but only one is shown here for clarity.

In order to identify a new chemotype as a potential back-up series to that exemplified by $\mathbf{1}$, we sought to leverage literature data through exploiting our knowledge of the binding mode of our existing leads. 
The basic strategy adopted is delineated in Figure 2.

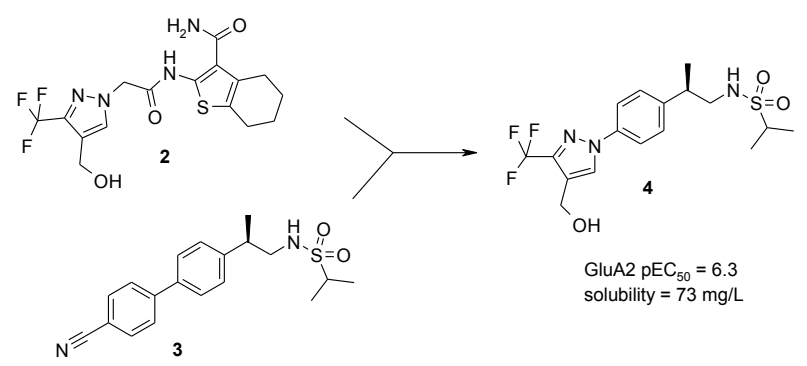

Figure 2. Lead series evolution through hybridization with literature compounds.

Compound 2, a hydroxyl containing analogue of $\mathbf{1}$ was considered to be a synthetically more expedient starting point and was shown to have similar potency and solubility $\left(\right.$ GluA1 $\mathrm{pEC}_{50}=6.4$, solubility $\left.=20 \mathrm{mg} / \mathrm{L}\right)$. We proposed to hybridize 2 with LY404187 (3) a AMPA receptor modulator which had previously been reported in the literature. [7] In addition, the X-ray cocrystal structure of $\mathbf{3}$ was known [8], thus facilitating detailed knowledge of how the compound interacted with the receptor. Preparation and subsequent characterization of $\mathbf{4}$ indicated that the hybridized compound retained an acceptable balance of potency and solubility.

In vitro, compound $\mathbf{4}$ was shown to have excellent microsomal stability (rat Cli $<12 \mu \mathrm{L} / \mathrm{min} / \mathrm{mg}$ protein, human $\mathrm{Cli}<12 \mu \mathrm{L} / \mathrm{min} / \mathrm{mg}$ protein) and reasonable permeability in a CaCo-2 assay, with no evidence of efflux $(A-B=206 \mathrm{~nm} / \mathrm{s}, \mathrm{B}-\mathrm{A}=287 \mathrm{~nm} / \mathrm{s})$. However, in vivo pharmacokinetic data was less promising $\left(\mathrm{Cl}_{\mathrm{p}}=\right.$ $49.7 \mathrm{~mL} / \mathrm{min} / \mathrm{kg} ; \mathrm{T}_{1 / 2}=1.0 \mathrm{~h} ; \mathrm{F} \%=3.2 ; 1 \mathrm{mg} / \mathrm{kg}$ dose (i.v.), $5 \mathrm{mg} / \mathrm{kg}$ (p.o.) using Wistar BRL rats). We hypothesized that improvement in oral bioavailability of 4 could be achieved through lowering clearance. Therefore, we considered conformational constraint of $\mathbf{4}$ with the expectation of being able to negate conformations predisposed to metabolism by CYP P450 enzymes. At the same time, we became aware of a related series of AMPA receptor modulators represented by 5 (Figure 3) [9] and thus sought to leverage these in our strategy of constraining our ligands.

Disappointingly, evaluation of $\mathbf{6}$ in the GluA2 functional assay indicated that the compound had only

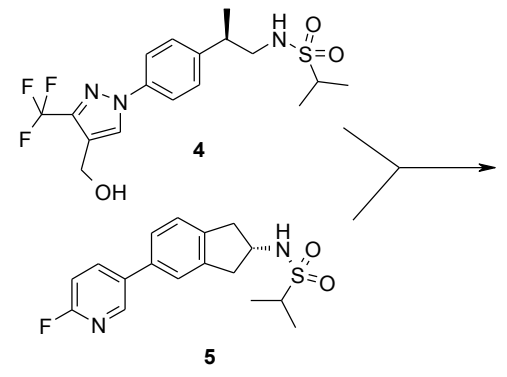

Figure 3. Introduction of conformational restraint.

weak activity as an AMPA receptor modulator (pEC50 $<4.5$ ). However, from consideration of the X-ray data of 4 in complex with the GluA2 S1S2 LBD, indicated that the pyrazole moiety did not interact with the receptor, which was in contrast with progenitor compounds such as 1 (Figure 4). In particular, the pendant trifluoromethyl group was not able to participate in a hydrophobic interaction with the receptor. We reasoned that insertion of a methylene spacer between the pyrazole group and central phenyl ring would be sufficient to restore this missing interaction. Preparation and testing of compound 7 (GluA2 $\mathrm{pEC}_{50}=6.3$ ) confirmed our hypothesis and further confirmation was provided upon solution of the X-ray co-complex of 7 with the GluA2 S1S2 LBD (Figure 4).

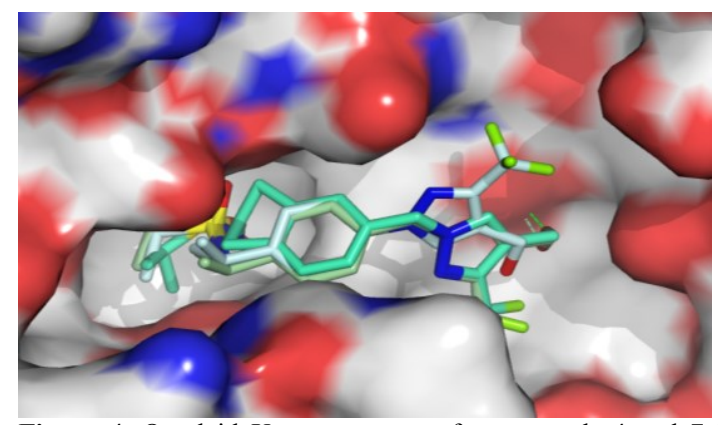

Figure 4. Overlaid X-ray structure of compounds 4 and 7 in complex with the GluA2 S1S2 LBD.

Compound 7 was shown to have good microsomal stability (rat Cli $31 \mu \mathrm{L} / \mathrm{min} / \mathrm{mg}$ protein, human Cli 23 $\mu \mathrm{L} / \mathrm{min} / \mathrm{mg}$ protein) and reasonable permeability in a $\mathrm{CaCo}-2$ assay, albeit with some suggestion of efflux (A$\mathrm{B}=128 \mathrm{~nm} / \mathrm{s}$, B-A = $290 \mathrm{~nm} / \mathrm{s}$ ). Pleasingly, in vivo pharmacokinetic data was vastly superior when compared to compound $\mathbf{4}$, with improved clearance and oral bioavailability. $\left(\mathrm{Cl}_{\mathrm{p}}=21.6 \mathrm{~mL} / \mathrm{min} / \mathrm{kg} ; \mathrm{T}_{1 / 2}=2.9 \mathrm{~h}\right.$; $\mathrm{F} \%=94 ; 1 \mathrm{mg} / \mathrm{kg}$ dose (i.v.), $5 \mathrm{mg} / \mathrm{kg}$ (p.o.) using Wistar BRL rats).

Having suitably benchmarked compound 7, our attention then turned to generation of SAR within this constrained series. Our initial focus was in the pyrazole region which proved to be quite flexible in terms of which modifications were tolerated (Table 1).

Table 1. Exploration of pyrazole region.

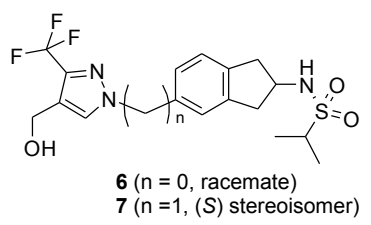

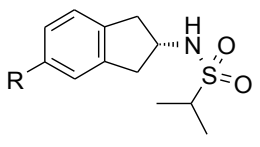

Compds

$\mathrm{R}$

$\mathrm{pEC}_{50}{ }^{\mathrm{a}}$ 
8

9

10

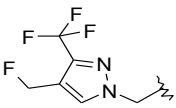

$$
\underbrace{F_{N}^{*}}_{=N}
$$

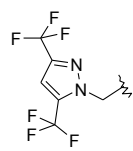

11

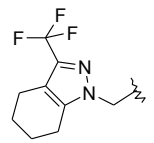

12

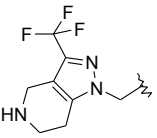

13

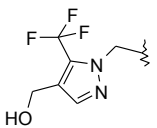

14

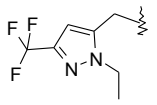

15

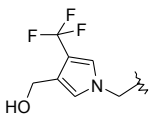

16

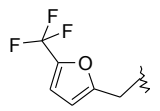

${ }^{a}$ Values are means of two experiments performed in duplicate.

Replacement (8) or homologation (9) of the pendant alcohol moiety had a minimal impact on potency. Similarly, incorporation of fragments (compounds $\mathbf{1 0}$ to 12) from our previously reported lead series $[4,5]$ was reasonably well tolerated, with compound $\mathbf{1 2}$ gaining additional potency, albeit at the expense of solubility $(<$ $1 \mathrm{mg} / \mathrm{L}$ ). The isomeric pyrazole system $\mathbf{1 3}$ was approximately ten-fold less potent, and this was attributed to the trifluoromethyl group being unable to make the same close hydrophobic contact with the receptor as in compound 7 . The C-linked pyrazole system in compound $\mathbf{1 4}$ was also of similar potency compared to the progenitor compound as was the pyrrole based moiety 15. Similarly, the furan derived system 16 demonstrated that diversification away from the original pyrazole motif could be achieved. Compound 16 was shown to bind to the receptor in a similar manner to 7 , with the trifluromethyl group making a hydrophobic interaction with the receptor (Figure 5).

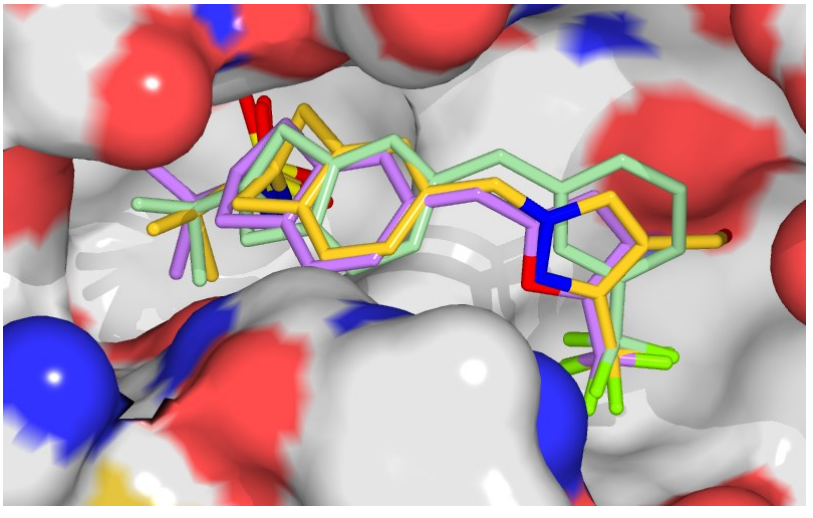

Figure 5. X-ray structure of compound $\mathbf{1 6}$ in complex with the S1S2J LBD of GluA2.

Having explored the pyrazole region of 7 , we subsequently focused on the indane sulfonamide portion of the molecule (Table 2).

Table 2. SAR exploration of indane sulfonamide region.

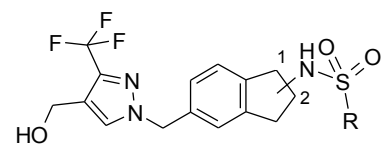

\begin{tabular}{|c|c|c|c|c|}
\hline Compds & Position & Stereochem & $\mathrm{R}$ & $\mathrm{pEC}_{50}^{\mathrm{a}}$ \\
\hline 7 & 2 & $S$ & $\overline{\mathrm{iPr}}$ & 6.3 \\
\hline 17 & 2 & $R$ & $\mathrm{iPr}$ & 6.4 \\
\hline 18 & 2 & $S$ & $\mathrm{CF}_{3}$ & 5.3 \\
\hline 19 & 2 & $R$ & $\mathrm{CF}_{3}$ & 5.6 \\
\hline 20 & 2 & $R$ & $\mathrm{cPr}$ & 5.6 \\
\hline 21 & 2 & $R$ & $\mathrm{NMe}_{2}$ & 6.0 \\
\hline 22 & 2 & $S$ & $\mathrm{Et}$ & 6.4 \\
\hline 23 & 2 & $S$ & $\mathrm{Me}$ & 5.1 \\
\hline 24 & 1 & $r a c$ & $\mathrm{iPr}$ & 7.0 \\
\hline 25 & 1 & $r a c$ & $\mathrm{cPr}$ & 6.8 \\
\hline 26 & 1 & rac & $\mathrm{Me}$ & 6.3 \\
\hline 27 & 1 & $\mathrm{rac}$ & & 5.7 \\
\hline 28 & 1 & $\mathrm{rac}$ & & 5.9 \\
\hline
\end{tabular}

${ }^{\mathrm{a}}$ Values are means of two experiments performed in duplicate.

Comparing enantiomeric pairs such as compounds $7 \&$ 17 and compounds $18 \& 19$ suggested that no distinct stereochemical preference existed within the series. Modification to the pendant isopropyl group was largely tolerated (19-23), although activity began to diminish when the size of the substituent was reduced (c.f. 22 and 23). Examination of the X-ray co-crystal structure of 7 points to the isopropyl group on the sulfonamide making a hydrophobic interaction with the receptor which accounts for the trend observed. Substitution from the 1-position of the indanyl system resulted in an increase in potency $(\mathbf{2 4})$ and related analogues $(\mathbf{2 5}, \mathbf{2 6})$ 
demonstrated a degree of flexibility in the SAR of this region, with aryl substituted sulfonamide derivatives being tolerated also $(27,28)$.

Following additional profiling of a number of compounds in the series, compound $\mathbf{1 9}$ emerged as having the best overall balance of potency and developability properties. These are summarized in Table 3.

Table 3. Developability properties of $\mathbf{1 9}$

\begin{tabular}{|c|c|}
\hline Property & $\overline{F-1}$ \\
\hline $\begin{array}{l}\text { Solubility } \\
\left(\mathrm{mg} . \mathrm{L}^{-1}\right)\end{array}$ & 84 \\
\hline Microsomal stability & $<12$ (rat) \\
\hline$\left(\right.$ Clint, $\left.\mu \mathrm{g} \cdot \mathrm{min}^{-1} \cdot \mathrm{mg}^{-1}\right)$ & $<12$ (human) \\
\hline Hepatocyte stability & $<6$ (rat) \\
\hline$\left(\right.$ Clint, $\mu 1 . \mathrm{min}^{-1}$. Mcells $\left.^{-1}\right)$ & \\
\hline Caco2 & 169(A-B ) \\
\hline$(\mathrm{nm} . \mathrm{s}-1)$ & $264(\mathrm{~B}-\mathrm{A})$ \\
\hline \multirow[t]{2}{*}{ Rat $\mathrm{PK}^{\mathrm{a}, \mathrm{b}}$} & $\mathrm{CL}=1.9 \mathrm{ml} /(\min . \mathrm{kg})$ \\
\hline & $\begin{array}{c}\text { Vss }=1.0 \mathrm{~L} / \mathrm{kg} \\
\mathrm{T}^{1} / 2=7.4 \mathrm{~h} \mathrm{~F} \%=100\end{array}$ \\
\hline $\mathrm{C}_{\max }$ Rat $\mathrm{CSF}^{\mathrm{c}}$ & $0.12 \mu \mathrm{M}$ \\
\hline
\end{tabular}

a $2 \mathrm{mg} / \mathrm{kg}$ i.v. dose Wistar BRL rats; ${ }^{\mathrm{b}} 10 \mathrm{mg} / \mathrm{kg}$ p.o. dose Wistar BRL rats; ${ }^{c} 2 \mathrm{mg} / \mathrm{kg}$ i.p. dose Wistar BRL rats.

Compound 19 displayed high aqueous solubility and excellent stability in both microsomal and hepatocyte preparations. Permeability was predicted to be good from the $\mathrm{CaCo}-2$ assay, with little evidence of efflux and this was mirrored in vivo with excellent oral bioavailability observed, along with low clearance and highly encouraging half life. CNS exposure was determined through measurement of drug concentration in CSF. This study showed good exposure and concentrations equivalent to the free drug in plasma, suggesting no efflux from the CNS. [10]

Synthesis of the compounds described above is outlined in Schemes 1 to 6. Sulfonylation of 29 (Scheme 1) followed by iodination and subsequent copper mediated arylation furnished 32. Reduction with $\mathrm{LiAlH}_{4}$ gave target compound 4. Compound 6 was accessed in an analogous fashion as illustrated in Scheme 2.

Compounds 7-11 were prepared as outlined in Scheme 3. Bromination of 2-aminoindane followed by resolution ${ }^{11}$ gave enantiomerically pure amine $\mathbf{4 0}$.

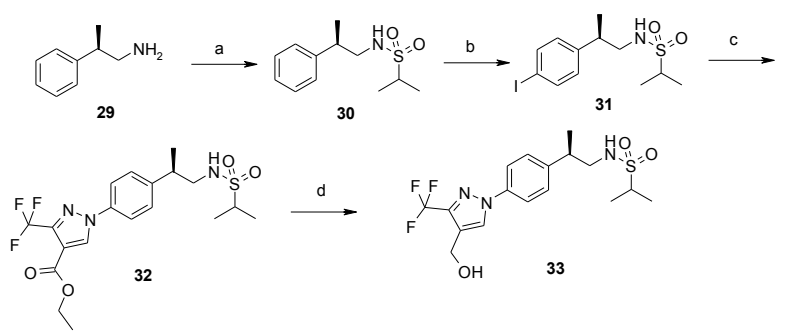

Scheme 1. Reagents and conditions: a) $\mathrm{iPrO}_{2} \mathrm{Cl}, \mathrm{Et}{ }_{3} \mathrm{~N}, \mathrm{DMAP}, \mathrm{CH}_{2} \mathrm{Cl}_{2}$, r.t., $87 \%$; b) $\mathrm{I}_{2}, \mathrm{H}_{2} \mathrm{SO}_{4}, \mathrm{AcOH}, \mathrm{H}_{5} \mathrm{IO}_{6}, \mathrm{H}_{2} \mathrm{O}, 5{ }^{\circ} \mathrm{C}, 70 \%$; c) ethyl-3(trifluoromethyl)pyrazole-4-carboxylate, $\mathrm{CuI}, \mathrm{N}, \mathrm{N}$-dimethylcyclohexane1,2-diamine, $\mathrm{K}_{2} \mathrm{CO}_{3}$, $\mathrm{PhMe}, 110{ }^{\circ} \mathrm{C}, 40 \%$; d) $\mathrm{LiAlH}_{4}$, THF, r.t., $52 \%$.

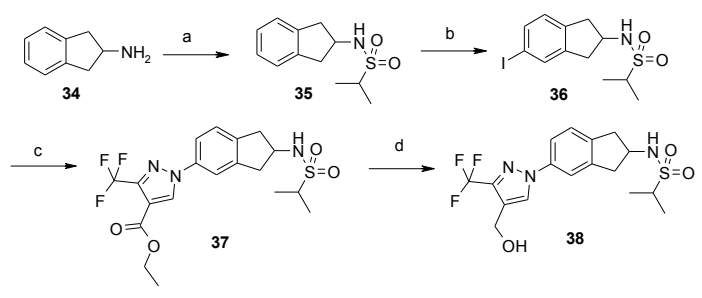

Scheme 2. Reagents and conditions: a) $\mathrm{iPrSO}_{2} \mathrm{Cl}, \mathrm{DBU}, \mathrm{CH}_{2} \mathrm{Cl}_{2}$, r.t., $88 \%$; b) $\mathrm{I}_{2}, \mathrm{H}_{2} \mathrm{SO}_{4}, \mathrm{AcOH}, \mathrm{H}_{5} \mathrm{IO}_{6}, \mathrm{H}_{2} \mathrm{O}, 5{ }^{\circ} \mathrm{C}, 56 \%$; c) ethyl-3(trifluoromethyl)pyrazole-4-carboxylate, $\mathrm{CuI}, \mathrm{N}, N$-dimethylcyclohexane1,2-diamine, $\mathrm{K}_{2} \mathrm{CO}_{3}$, $\mathrm{PhMe}, 110{ }^{\circ} \mathrm{C}, 16 \%$; d) $\mathrm{LiAlH}_{4}$, THF, r.t., $88 \%$.

Sulfonylation followed by palladium mediated carbonylation and reduction gave alcohol 43 which could then be chlorinated and used to alkylate the appropriate azole derivative. Compound $\mathbf{8}$ was obtained directly from 7 by treatment with DAST, while compound 13 could be obtained via careful chromatographic separation from 7 .

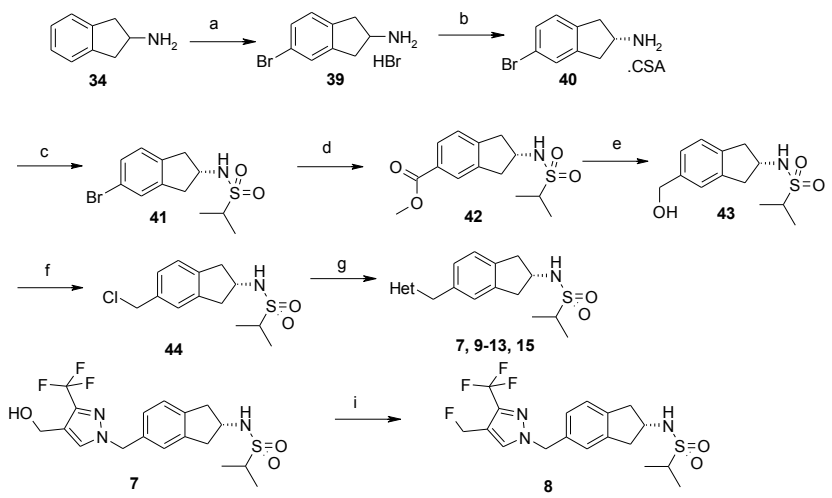

Scheme 3. Reagents and conditions: a) $\mathrm{Br}_{2}, \mathrm{H}_{2} \mathrm{O}, 60{ }^{\circ} \mathrm{C}, 56 \%$; b) Lcamphorsulfonic acid, $\mathrm{NMO}, \mathrm{MeOH}, 65^{\circ} \mathrm{C}, 26 \%$; c) $\mathrm{iPrSO}_{2} \mathrm{Cl}, \mathrm{DBU}$, $\mathrm{CH}_{2} \mathrm{Cl}_{2}, 0^{\circ} \mathrm{C}, 93 \%$; d) acetoxy(2-(dio-tolylphosphino)benzyl)palladium, $\mathrm{PB}_{3} \mathrm{Bu}_{3} \cdot \mathrm{HBF}_{4}, \mathrm{DBU}, \mathrm{MeCN} / \mathrm{MeOH}, 150{ }^{\circ} \mathrm{C}, \mu \mathrm{W}, 88 \%$; e) $\mathrm{LiAlH}_{4}, \mathrm{THF}$, $0^{\circ} \mathrm{C}, 100 \%$; f) $\mathrm{SOCl}_{2}, \mathrm{CH}_{2} \mathrm{Cl}_{2}$, r.t., $100 \%$; g) azole derivative, $\mathrm{NaH}, \mathrm{DMF}$, $60{ }^{\circ} \mathrm{C}, 19-55 \%$; i) DAST, $\mathrm{CH}_{2} \mathrm{Cl}_{2}, 20 \%$.

Scheme 4 outlines the preparation of analogues 14 and 16. The boronate ester 45 was prepared and used in a palladium catalysed $\mathrm{sp}^{2}-\mathrm{sp}^{3}$ coupling [12] to furnish both target compounds. 


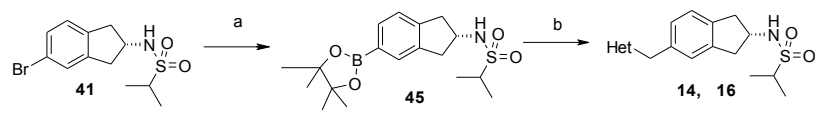

Scheme 4. Reagents and conditions: a) bis(pincolato)diboron, $\mathrm{Pd}(\mathrm{dppf}) \mathrm{Cl}_{2}, \mathrm{KOAc}, \mathrm{DMF}, 60{ }^{\circ} \mathrm{C}, 41 \%$; b) $\mathrm{HetCH}_{2} \mathrm{Cl}, \mathrm{Pd}_{2}(\mathrm{dba})_{3} \cdot \mathrm{CHCl}_{3}$ complex, $\mathrm{PPh}_{3}, \mathrm{NBS}, \mathrm{Na}_{2} \mathrm{CO}_{3}, 100{ }^{\circ} \mathrm{C}, \mu \mathrm{W}, 16-20 \%$.

Sulfonamide derivatives $\mathbf{1 7}$ to $\mathbf{2 3}$ were prepared according to the synthetic plan delineated in Scheme 5. Resolution of aminoindane 39 with either L- or D-CSA gave $(S)$ or $(R)$ enantiomers, respectively. $\mathrm{Cbz}$ protection followed by carbonylation and subsequent reduction gave $\mathbf{5 0 a / 5 0 b}$ as separate compounds, both of which could be converted to the chloride derivative and used to alkylate the requisite pyrazole alcohol. Protecting group removal followed by the final diversity step gave target compounds $\mathbf{1 7 - 2 3}$ as discrete enantiomers.

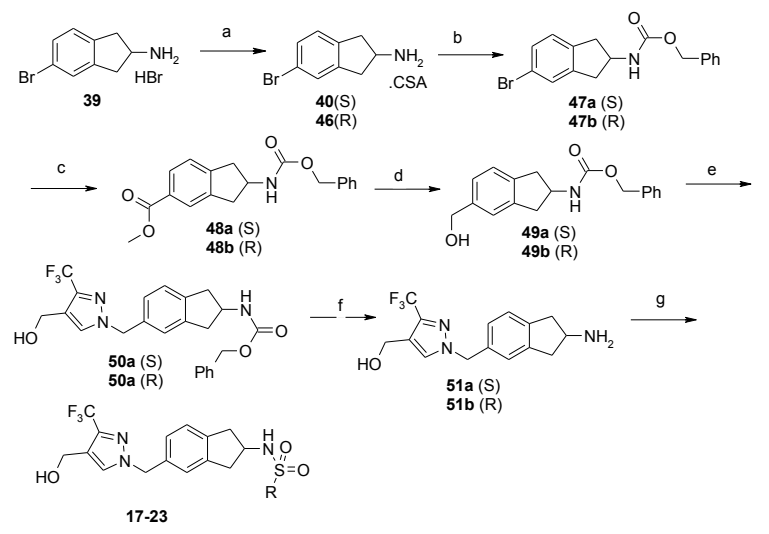

Scheme 5. Reagents and conditions: a) D or L-camphorsulfonic acid, $\mathrm{NMO}, \mathrm{MeOH}, 65^{\circ} \mathrm{C}, 26-30 \%$; b) benzyl chlorformate, $\mathrm{K}_{2} \mathrm{CO}_{3}$, EtOAc/water; $100 \%$; c) acetoxy(2-(dio-tolylphosphino)benzyl)palladium, $\mathrm{P}^{\mathrm{t}} \mathrm{Bu}_{3} \cdot \mathrm{HBF}_{4}, \mathrm{DBU}, \mathrm{MeCN} / \mathrm{MeOH}, 150{ }^{\circ} \mathrm{C}, \mu \mathrm{W}, 89-93 \%$; d) $\mathrm{LiBH}_{4}, \mathrm{THF}$, r.t., $48-51 \%$; e) i. $\mathrm{SOCl}_{2}, \mathrm{CH}_{2} \mathrm{Cl}_{2}$, r.t. ii. (3-(trifluoromethyl)-1Hpyrazolyl-4-yl)methanol, $\mathrm{K}_{2} \mathrm{CO}_{3}, 60{ }^{\circ} \mathrm{C}, 77-81 \%$ (over 2 steps); f) $\mathrm{Pd}(\mathrm{OH})_{2}, \quad \mathrm{EtOH} / 5 \mathrm{~N} \mathrm{HCl}, \mathrm{H}_{2}$ (2bar), 66-71\%; g) sulfonyl chloride derivative or $\left(\mathrm{CF}_{3} \mathrm{SO}_{2}\right)_{2} \mathrm{O}$ (for $\left.18 \& 19\right), \mathrm{Et}_{3} \mathrm{~N}, \mathrm{CH}_{2} \mathrm{Cl}_{2}, 17-71 \%$.

Compounds 24 to $\mathbf{2 8}$ were prepared in an analogous fashion to the above starting from 5-bromo-2,3-dihydro$1 \mathrm{H}$-inden-amine (53) which is prepared through via reduction of an oxime intermediate derived from 5bromoindan-1-one (52, Scheme 6).

In summary, this work has that key component of our scaffold hopping strategy has been the application of SBDD against an ion channel targe in directing our template modifications as well as offering key insights into SAR within the series. Starting from a lead compound 1, we have demonstrated how this can be optimized to yield a structurally differentiated entity (19) with an excellent overall balance of properties. We believe 19 will be a valuable tool in further understanding the role of AMPA receptor modulators in complex neurological disorders.
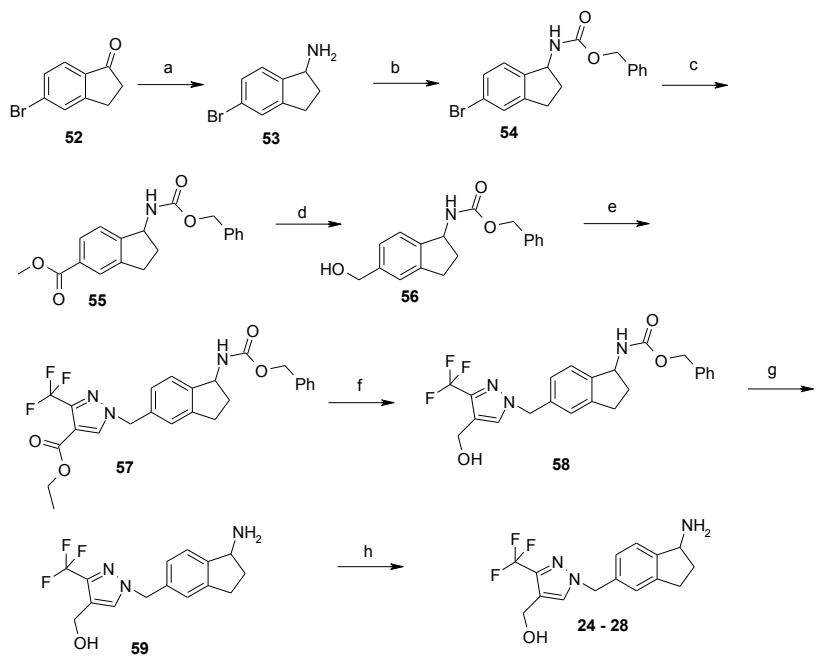

Scheme 5. Reagents and conditions: a) i. $\mathrm{NH}_{2} \mathrm{OH} \cdot \mathrm{HCl}$, EtOH, reflux ii. $\mathrm{Zn}, \mathrm{AcOH}$, r.t. $68 \%$ (over 2 steps) b) benzyl chlorformate, $\mathrm{K}_{2} \mathrm{CO}_{3}$, EtOAc/water; 67\%; c) acetoxy(2-(dio-tolylphosphino)benzyl)palladium, $\mathrm{P}^{\mathrm{t}} \mathrm{Bu}_{3} \cdot \mathrm{HBF}_{4}, \mathrm{DBU}, \mathrm{MeCN} / \mathrm{MeOH}, 150{ }^{\circ} \mathrm{C}, \mu \mathrm{W}, 77 \%$; d) $\mathrm{LiAlH}_{4}, \mathrm{THF}$, r.t., $48 \%$; e) i. $\mathrm{SOCl}_{2}, \mathrm{CH}_{2} \mathrm{Cl}_{2}$, r.t. ii. Ethyl (3-(trifluoromethyl)-1Hpyrazolyl-4-yl)carboxylate, $\mathrm{K}_{2} \mathrm{CO}_{3}, 60{ }^{\circ} \mathrm{C}, 84 \%$ (over 2 steps); f) $\mathrm{LiAlH}_{4}$, THF, r.t., $74 \%$ g) $\mathrm{Pd}(\mathrm{OH})_{2}$, EtOH $/ 5 \mathrm{~N} \mathrm{HCl}, \mathrm{H}_{2}(2 \mathrm{bar}), 83 \%$; h) sulfonyl chloride derivative, $\mathrm{Et}_{3} \mathrm{~N}, \mathrm{CH}_{2} \mathrm{Cl}_{2}, 24-32 \%$.

\section{References}

1. Kew, J. N. C. and Kemp, J. A. Psychopharmacology 2005, 179, 4.

2. Marenco, S. and Weinberger, D. R. CNS Drugs 2006, 20, 173.

3. Zarate, J. and Manji, H. K. Exp. Neurology 2008, 211, 7. 4. Jamieson, C. et al Bioorg. Med. Chem. Lett. 2010, 15, DOI: $10.1016 /$ j.bmcl.2010.07.138

5. Jamieson, C. et al Bioorg. Med. Chem. Lett. 2010, 15, accepted for publication.

6. Armstrong, N.; Sun ,Y.; Chen, G. Q.; Gouaux, E. Nature 1998, 395, 913.

7. Quirk, J. C. and Nisenbaum, E. CNS Drug Rev. 2002, 8, 255.

8. Sobolevsky, A. I.; Rosconi, M. P.; Gouaux, E. Nature 2009, 462, 745 .

9. Ward, S. E.; Harries, M.; Aldegheri, L.; Andreotti, D.; Ballantine, S.; Bax, B. D.; Harries, A. J.; Harker, A. J.; Lund, J.; Melarange, R.; Mingardi, A.; Mookherjee, C.; Mosley, J.; Neve, M.; Oliosi, B.; Profeta, R.; Smith, K. J.; Smith, P. W.; Spada, S.; Thewlis, K. M.; Yusaf, S. P. J. Med. Chem. 2010, 53, 5801.

10. Lin, J. H. Curr.Drug Metab. 2008, 9, 46.

11. Prashad, M.; Hu, B.; Har, D.; Repic, O.; Blacklock, T. J.; Acemoglu, M. Adv.Synth. Catal. 2001, 343, 461-472. 12. Burns, M. J.; Fairlamb, I. J. S.; Kapdi, A. R.; Sehnal, P.; Taylor, R. J. K. Org. Lett. 2007, 9, 5397. 